2. Бархударов Л. С. Мова і переклад. М. : Міжнародні відносини. 1975. $235 \mathrm{c}$.

3. Зарицький M. С. Переклад: створення та редагування. K., 2004. 120 c.

4. Кінаш Б. М. Формування науково-технічних термінів 3 дієприкметниками. Львів : Вид-во Нац. ун-ту «Львівська політехніка», 2002. $36 \mathrm{c}$.

5. Ковганюк С. П. Практика перекладу. К., 1968. 274 с.

6. Комісаров В. Н. Лінгвістика перекладу. М. : Міжнародні відносини, $1980167 \mathrm{c.}$

7. Найда Ю. А. Процедура аналізу компонентної структури референційного значення. М., 1983. 120 с.

8. Федоров А. В. Основи загальної теорії перекладу. М. : ООО Філологія три, 2002. 416 с.

DOI https://doi.org/10.30525/978-9934-26-073-5-2-35

\title{
ПЕРЕКЛАДАЦЬКІ ТРАНСФОРМАЦІЇ ПРИ ВІДТВОРЕННІ ПОБУТУ ЯК МАРКЕРА СОЦАЛЬНОГО СТАТУСУ ПЕРСОНАЖА НА ОСНОВІ РОМАНУ ОСКАРА УАЛЬДА «ПОРТРЕТ ДОРІАНА ГРЕЯ»
}

\author{
Ситюк В. В. \\ студентка 5 курсу кафедри англійської філології і перекладу \\ Національного авіаційного університету \\ м. Київ, Украӥна
}

Перекладацькі трансформації є невід'ємною частиною перекладу усіх творів. Саме тому ця тема досі цікавить багатьох науковців та вчених, як вітчизняних так $\mathrm{i}$ зарубіжних. Вивчення питання застосування трансформацій у перекладі побуту як маркеру соціального статусу персонажів неодноразово розглядалося такими дослідниками як-от: О. Лукашевич, О. Удод, В. Коцур, Jr. Gregory, W. Stanford та ін. Однак не зважаючи на те, що переклад побуту аналізувався багатьма науковцями, шляхи його відтворення в епоху Вікторіанської Англії все ще знаходяться на периферії перекладознавства, що й обумовлює актуальність даного дослідження.

До маркерів побуду ми відносимо усі ті лексеми, які описують життя Вікторіанської Англії в деталях, які характерні для Англії. Дана епоха 
припадала на часи правління королеви Великої Британії Вікторії. Для досягнення адекватності та еквівалентності при їх перекладі варто враховувати норми мови, історичний період, у якому розвивалися події та мовленнєві традиції культури мови перекладу. Часто під час перекладу виникає проблема можливості спотворення змісту тексту й це призводить до неможливості здійснення прямого перекладу у певній ситуації. Саме тому доцільно використувати групи прийомів, які виділяють Т. Левицька або Ж. Дарбельне. У своєму дослідженні ми скористалися класифікацією Т. Левицької. Загальновідомо, що вона поділяла їх на три типи: граматичні (опущення й додавання, перестановки, перебудови, зміни синтаксичних конструкцій); стилістичні, до яких належать такі прийоми як синонімічні заміни та описовий переклад, компенсація; лексичні (опускання, заміну, додавання, конкретизацію та генералізацію) [2]. За основу порівняльно-перекладознавчого аналізу відтворення побуту як маркера соціального статусу персонажа ми обрали твір Вікторіанської епохи Оскара Уальда «Портрет Доріана Грея».

Розглянемо цитату з оригінального тексту та його перекладу:

There is a fatality about all physical and intellectual distinction, the sort of fatality that seems to dog through history the faltering steps of kings [6, c. 5].

Всіма, хто має непересічний розум чи красу, правує в житті лихий фатум, - той самий, що спрямовував непевну ходу монархів протягом yсієї iсторії [1, c. 3].

У даному випадку автор використовує такий прийом стилістичної трансформації, як синонімічна заміна. Оскільки іменник «king» в українській мові має еквівалент - «король», а монарх - це синонім, що у СУМ означає «єдиновладний голова держави (король, цар, імператор і т. ін.)» [3], то перекладач вирішив замінити його на синонім притаманний мові перекладу й кращого порозуміння повноважень правлячої особи читачами.

Далі, у рамках розвідки, проаналізуємо приклад використання граматичної трансформації:

«Well, I can tell you anything that is in an English Blue Book, Harry, although those fellows nowadays write a lot of nonsense [6, c. 27].

- Ну шо ж, я можу тобі розповісти що завгодно з англійських Синіх книг, хоча чі теперішні діячі заводять туди безліч нісенітниць [1, с. 22].

Тут спостерігаємо заміну однини в тексті оригіналу на множину в тексті перекладу : an English Blue Book - англійських Синіх книг, щоб надати більш загальну картину, не змушуючи читача думати й шукати інформацію про книгу. 
У наступній цитаті ми маємо змогу проаналізувати використання лексичної трансформації:

On and on plodded the hansom, going slower, it seemed to him, at each step. He thrust up the trap and called to the man to drive faster. The hideous hunger for opium began to gnaw at him. His throat burned and his delicate hands twitched nervously together. He struck at the horse madly with his stick. The driver laughed and whipped up. He laughed in answer, and the man was silent [6, c. 143].

A кеб котив усе далі й далі $i$ з кожною хвилиною немовби все повільніш. Доріан відхилив віконце й гукнув до кучера їхати ивидие. Його пекла хіть опію, горло пересохло, пещені руки конвульсійно стискалися. У нестямі він ударив коня своєю тростиною. Кебмен засміявся і собі хвисьнув батогом. Доріан засміявся теж, але кучер стих [1, c. 121].

У цьому прикладі спостерігаємо опис пересування на екіпажі. Сам пристрій називається «the hansom», що в англійській мові означає «а twowheeled carriage pulled by a horse, used like a taxi in the past» [5]. В українській мові існує запозичене слово «кеб»у значені «найманий екіпаж на кінній тязі, поширений був переважно у Великій Британії в XVII-XIX століттях. Тобто «кеб»- це рівноцінний еквівалент до слова «the hansom». Той, хто ним керує, в англійській мові називають «The driver», тобто водій. Цікаво, що в англійському варіанті ми бачимо використання двох загальних слів - «the driver» та «the man», де перше більш конкретніше за друге. У той час як в перекладі навпаки конкретні назви професії «водія екіпажу»: «кебмен» та «кучер» - «розм. те саме, що візник» [3]. В обох варіантах застосовано конкретизацію: the driver - кебмен; the man - кучер, що влучно допомагає відтворити професію тієї епохи. Одразу відмітимо, що така стратегія є прийнятою у перекладі, позаяк забезпечує адекватне сприйняття мовних особливостей в рамках іншого культурного / соціального континууму [4, с. 93].

Отже, здійснивши порівняльний аналіз оригіналу та перекладу роману Оскара Уальда «Портрет Доріана Грея», ми розглянули окремі випадки застосування різних перекладацьких трансформацій задля досягнення адекватності та еквівалентності перекладу. Для досягнення адекватності перекладач використовував лексичні та граматичні трансформації, а також семантичні прийоми для передачі побуту Вікторіанської епохи в Англії. Завдяки їх використанню вторинному комуніканту вдається більш вдало перенести особливості певної епохи у цільовий текст. 


\title{
Література:
}

1. Вайльд О. Портрет Доріана Ірея: Роман: Для ст. шк. віку / Пер. $з$ англ. та прим. Р. Доценка; К.: Школа, 2003.

2. Левицкая, Т.Р. Теория и практика перевода с английского языка на русский. М., 1963. 125 с.

3. Словник української мови URL: http://sum.in.ua/s/kucher

4. Струк І.В. Стратегії відтворення аномалій діалектного мовлення в перекладі (на матеріалі творів Марка Твена та їхніх перекладів українською та російською мовами). Гуманітарна освіта в технічних вищих навчальних закладах: зб. наук. праць. К.: Університет «Україна», 2014. Вип. 30. С. 83-97.

5. Cambridge Internetional Dictionary of English. Cambridge University Press. 2021 URL:https://dictionary.cambridge.org/dictionary/english

6. Wilde O. The picture of Dorian Gray. OriginalBook.ru, 1890.

DOI https://doi.org/10.30525/978-9934-26-073-5-2-36

\section{СПЕЦИФІКА ВІДТВОРЕННЯ ДІАЛЕКТИЗМІВ ФОНОГРАФІЧНОГО РІВНЯ ТВОРІВ ЕЛЕОНОР ПОРТЕР}

\author{
Струк I. B. \\ кандидат філологічних наук, \\ дочент кафедри англійської філології і перекладу \\ Національного авіаційного університету \\ Кривенко В. М. \\ студентка четвертого курсу \\ кафедри англійської філології і перекладу \\ Національного авіачійного університету \\ м. Київ, Україна
}

Діалекти часто відносили до неперекладного явища за рахунок розбіжностей, котрі існують у рамках різних мовних систем. I побоювання не без підставне адже, дві мови - два різних мовних континуума, живуть за різними правилами та піддаються різним процесам фонації. Звідси, коли мова іде про діалект, завдання перекладача, котре полягає у здійсненні еквівалентного відповідника стає непідйомним тягарем для перекладача, принаймні так вважалося до середини XX століття. Оскільки мовні особливості приймають вигляд ребуса відкрити ритмічну 